\title{
Building Natural and Cultural Tourism Entities Through Visual Space of Television Shows: Analysis of "My Trip My Adventure" Program
}

\author{
Dendi Pratama ${ }^{1}$, Winny G W Wardani ${ }^{2}$ and Santi Sidhartani ${ }^{3}$ \\ Faculty of Language and Art, Universitas Indraprasta PGRI, Jakarta Selatan, Indonesia ${ }^{1,2,3}$ \\ \{dendi.pratama@unindra.ac.id $\left.{ }^{1}\right\}$
}

\begin{abstract}
My Trip My Adventure from Trans TV is an interesting viewing program because it elevates the potential of cultural tourism and Indonesia's natural wealth from Sabang to Merauke. This program has been aired since 2013 and is in line with the vision of the Ministry of Tourism to make Indonesia a world tourist center, including the Visit Wonderful Indonesia campaign and the target of 20 million tourists in 2019. My Trip My Adventure has a number of advantages. In 2015, this program was selected as a show with good quality according to a television broadcast survey version of the Indonesian Broadcasting Commission, and in 2016-2017 received the Indonesia Choise Award for the nomination of TV Program of the Year. This study examines, how the design of My Trip My Adventure can build natural and cultural tourism entities through the visual space of television. This study shows the relation of elements in the visual space as entities that carry messages. Qualitatively, this study describes visual language in design using a television journalistic approach, especially in the composition of images and the size of shooting as a design in the visual space of television. Analysis is based on the results of quantitative data on the quantity of shoot sizes. The study of My Trip My Adventure can be a reference on television design knowledge that is able to provide information, education, and entertainment, while inviting the audience to understand the visual strength in television shows, so that viewers can explore, adventure, and be encouraged to promote Indonesian natural and cultural tourism.
\end{abstract}

Keywords: Tourism, television, culture.

\section{Introduction}

Indonesia, with its natural beauty and cultural wealth, places it as a country with worldclass tourism potential. The World Travel \& Tourism Council (WTTC), in the last quarter of 2018, has announced the position of Indonesia which is ranked ninth in the growth of the tourism sector. The results of the WTTC version of research, presented by the Minister of Tourism AriefYahya, also confirmed that Indonesia's tourism sector has the potential to be the biggest national foreign exchange contributor. This can be seen from the growth rate of Indonesia's tourism which reached 22 percent in 2017, exceeding the average growth of world tourist growth of 6.4 percent, and the growth of tourists in ASEAN by 7 percent [1]. 
This fact prompted the Indonesian Ministry of Tourism (Kemenpar) to improve its tourism programs, including through Visit Wonderful Indonesia (ViWi). The Indonesian tourism promotion video entitled "Wonderful Indonesia: the Journey of a Wonderful World", in 2017 even managed to win a competition organized by the UN World Tourism Organization (UNWTO) and the People's Choice Award, beating tourism promotion videos from 63 other countries [2]. Since 2016 until now, the promotional video "Wonderful Indonesia" has also been regularly aired on various television channels, both in Indonesia and other countries in the world, including the program "Horizons d'Asie" on French TV.

Televisionis still a vital information medium in the current era of information technology advances. Television can also be a medium of promotion because it has social and cultural strengths. Danesi said, television media has the power because it becomes a kind of sign called social text, which is a culture that has become a daily routine of humans[3]. Watching television has become an obligation, and is no longer limited to community rights, which now has a high level of dependence on audiovisual technology. Therefore, efforts to support Indonesia's tourism program through television media are interesting to study and need to get public attention.

This study discusses one of Indonesia's tourist documentation programs which includes the audience choice program, namely "My Trip My Adventure" (MTMA) from Trans TV. The program that aired since September 2013, in 2016 and 2017 won the Indonesian Choice Award. The program has also been named as one of the best quality shows according to a television show quality survey, the Indonesian Broadcasting Commission (KPI) version from September to October 2015. In 2017, the MTMA Community, which consists of more than 2000 members covering 80 regions, also synergized with the Ministry of Tourism to promote the Wonderful Indonesia program more broadly by targeting millennials who like adventure and technology literacy [4].

MTMA program displays documentation of Indonesia's natural beauty and cultural tourism from a range of regions including East Indonesia to Western Indonesia, guided by two or more presenters, young people who are attractive, energetic, intimate way of communication, and fashionable. Exploration of the coast, the charm of the sea, hills and mountains, from various regions from Sabang to Merauke, are presented in episodes that highlight visual strength through long and close shooting techniques. It also equipped with information about location, cultural traditions,social life of the community, and important things that must be known by tourists when they reach the place.

Thecase study of MTMA is about the importance of building an entity in television programs, especially in terms of visual appearance of images as an effort to attract the attention of television viewers. Presenting entities in a show is also part of the television business communication strategy. Entities in the context of television shows are unity, which are born with specific characteristics as spectacle. An entity can manifest as an event, activity, or attitude towards human needs in its efforts to find relationships in its social environment.

In visual culture, the MTMA program is interesting to study, especially in the context of the visualization of the space that appears on the screen. As a spectacle design, MTMA builds the audience's perception through a visual space about the beauty and natural wealth of Indonesia. The study also formulated research questions as the main discussion, namely: How is the visual space in the MTMA program designed as visual elements that build natural and cultural tourism entities?

The discussion of this study is described qualitatively by the television journalistic approach, namely the shooting technique includes the composition of images and the size of shooting on the screen as a visual space that carries messages. Analysis is based on the 
quantitative data results on the quantity of the sizes of shooting. This study seeks to describe the meaning of the sign in a show that is focused on nonverbal visual elements, as a study that also provides a public understanding of visual culture products. The study of the MTMA program can be a reference about television design knowledge and encourages audience understanding of shows that are able to provide information, education, and entertainment. The purpose of this study also invites the public to understand thevisuals strength that are able to invite television viewers to explore, experience adventure and encourage young people to help promote Indonesian natural and cultural tourism.

\section{Literature review}

Theoretically, a television program was created to meet various communication purposes. Although the genre of television shows is divided according to the genre of information and entertainment, in the practice of broadcasting, these two genres are often inseparable. This is because television shows must be designed to meet and satisfy the needs of the audience who tend to be selective because of the large variety of programs offered by hundreds of television channels today.

\subsection{Visual Spaceon a Television Screen}

Viewing images on a television screen means watching through a visual space. Block said, visual space on television can be interpreted as the space seen on the screen by the audience[5]. However, the process of seeing television images is basically not just visual activity. The act of seeing is only part of the perception. Primarily the viewer must understand what they sees which is called the constructionist viewpoint. The viewers can read and understand messages conveyed through images as elements in a visual space, based on views that depend on the use of language or visual and verbal codes, technical codes, clothing codes, etc. that are delivered by television to the eyes and ears[6].

Morissan describes the existence of two forms of television programs, namely the dominance of the format and the dominance of participants as television stars[7]. Both of these forms are aspects of the strategy to achieve the success of the program. One of these forms can be more dominant or both balanced. For the discussion of natural and cultural tourism entities at "My Trip My Adventure" (MTMA), this study refers to an understanding of visual language reading in visual space, which is presented through a program form by analyzing the composition of images and the size of shooting as visual elements designed through camera movement.

In MTMA shows, the dominance of the format is represented by the format of shooting. The visual space display is designed to represent the eyes of the audience who have a desire to explore natural and cultural tourism in Indonesia. While the dominance of the star is represented by the presence of beautiful and handsome hosts who generally become the idol of the millennial generation, of which the performers are Vicky Nitinegoro, Hamish Daud, Nadine Chandrawinata, Denny Sumargo, Dion Wiyoko, Marshall Sastra, and Putri Marino. The host of the show as the star's dominance was presented alternately. 


\subsection{Television Journalistic Approach: the Composition of Images and the Size ofShooting}

In television journalism, the angle of shooting and how the image is displayed on the screen has an important role because it can form the depth of the image and build psychological effects that affect the viewers' thoughts and feelings, thus building pleasure in consuming visual culture. Walker and Chaplinsaid, visual culture provides aesthetic pleasure and most discussions about pleasure focus on the audience experiences. In other words, watching television is part of the audience's experience, and how that experience and pleasure is built through images[8].

In the television journalistic approach, Fachruddindescribes the understanding of image composition as placing elements of a picture into a frame, called the Rule of Thirds or the Golden Mean, namely three parts vertically, and three parts horizontally[9]. The intersection of vertical and horizontal lines becomes the attention point of the audience, where interest point of object should be placed at these intersection points. As for the size of shooting, the technique is divided into nine categories, namely:

1. Extreme long shot (ELS), is shooting as strength to establish an event or scene that is very far, long, wide, wide dimension. Usually used for the composition of the beauty of the image in a panorama.

2. Very long shot (VLS), is shooting for an opening scene or a colossal bridging scene, the image is in the camera's top angle position.

3. Long shot (LS), is the overall shooting in landscape format to display the breadth of the atmosphere and object

4. Medium long shot (MLS), is shooting for enrich the beauty of the scenery.

5. Medium shot (MS), is a half body shot more to show the expression and emotions of the star.

6. Middle close up (MCU), is half-body portrait shooting with the flexibility of the background that can still be enjoyed.

7. Close up (CU), is shooting that focuses on the face to describe someone's emotions or reactions, and explore hidden attraction.

8. Big close up (BCU), is a sharper close up image to reveal the depth of facial expressions, eyes, or objects in the form of objects that require details.

9. Extreme close up (ECU), is shooting with proximity and sharpness that focuses on one object to have a dramatic effect.

Thus the theoretical basis is used as references to analyze natural and cultural tourism entities at MTMA shows

\section{Result and discussion}

MTMA airs every Saturday and Sunday at 8:30 with a duration of 90 minutes. This study took three samples randomly from MTMA shows during the last three months in 2018, September, October and November. Choices are based on new shows, each with the title: "Berbagai Keindahan di Bumi Cenderawasih Jayapura Papua" (September 8, 2018), "Sejuta Pesona Pulau Komodo" (October 6, 2018), and "Trip Seru Ga Perlu Jauh! Di Bogor Juga Bisa!" (November 17, 2018). The results of the data show the quantity of shooting sizes in the three samples are as follows:

Table 1.Quantity of the Sizes of Shooting 


\begin{tabular}{lcccc}
\hline & $\begin{array}{c}\text { MTMA } \\
\text { (September 8, 2018) }\end{array}$ & $\begin{array}{c}\text { MTMA } \\
\text { October 6, 2018) }\end{array}$ & $\begin{array}{c}\text { MTMA } \\
\text { (November 17, 2018) }\end{array}$ & $\begin{array}{c}\text { Total } \\
\text { Shot }\end{array}$ \\
\hline ELS & 10 & 25 & 13 & 48 \\
VLS & - & 10 & 1 & 11 \\
LS & 30 & 30 & 18 & 78 \\
MLS & 30 & 30 & 38 & 98 \\
MS & 23 & 5 & 10 & 38 \\
MCU & 11 & - & - & 11 \\
CU & 1 & 4 & 3 & 8 \\
BCU & 8 & - & 3 & 11 \\
ECU & - & - & - & -
\end{tabular}

The quantitative data above shows the visual strength of three dominant shots, namely: Extreme Long Shot (ELS), Long Shot (LS), and Medium Long Shot (MLS). The three types of shots aim to display the beauty of the panorama, and simultaneously sharpen the richness of the object. Taking this type of image needs to consider the composition, because it affects the overall image of the object. A good shot is a combination of various compositions of images into the connection of a whole and beautiful image in one shot. For this reason, it is important to know the meaning of a shot, so that the images displayed do not confuse the audience [10].

The MTMA program also combines the dominance of formats and star domination as interactive participants, as explained by Krees and van Leeuwen as an illustration of the interaction between people seen on the screen, including communicating with the audience. In addition, this show also features a fun atmosphere, so information is delivered in a way that entertains and spoils the eyes of the audience[11].

Furthermore, based on the three dominant types of shoots, natural and cultural tourism entities can be described that are built in the visual space. The message of the entity as a form of visual strength of visual language is described as follows:

Table 2.Visual Space of the Natural and Cultural Tourism Entities

\begin{tabular}{ll}
\hline \multicolumn{1}{l}{$\begin{array}{l}\text { Extreme Long Shot Domposition of Images } \\
\text { (ELS) }\end{array}$} & Entities \\
Long Shot (LS) $\quad$ Dominance of the middle frame & $\begin{array}{l}\text { Realizing the visual strength of the } \\
\text { beauty of the panorama } \\
\text { Realizing the visual strength of } \\
\text { interactive participants between } \\
\text { people, places, including the audience }\end{array}$ \\
$\begin{array}{l}\text { Medium Long ShotDominance of the middle frame } \\
\text { (MLS) }\end{array}$ & $\begin{array}{l}\text { Realizing visual strength that enriches } \\
\text { and sharpens the beauty of panoramas } \\
\text { and interactions in socio-cultural } \\
\text { environments }\end{array}$ \\
\hline
\end{tabular}

The message of the entity that builds perceptions about the beauty of Indonesia's natural and cultural tourism is important because the MTMA program is part of a media campaign to increase tourism targets. According to Mingkid, the government is responsible for informing 
tourism programs to the general public, and optimizing the use of information technology to eliminate barriers to bureaucratic organizations, forming a network of management systems and work processes, so that the government, private sector and society can work in an integrated manner promoting tourism potential to the general public[12].

Visualizing Indonesia's natural beauty, which is the visual strength of MTMA, can indirectly encourage ecotourism, namely nature-based tourism that is not consumptive and locally oriented. Ecotourism can also be a model of natural use by empowering local communities to manage it so that it has the lowest impact on the environment [13].

MTMA is designed to meet the information needs of today's society who also play a role as citizen journalism, where they can disseminate information through social media. Entities that are built through MTMA can encourage massive information dissemination, especially through youtube media, as long as the visual strength can fulfill the desires of the adventurous audience.

Respati also said, that increasingly convergent communication devices had a big contribution in the changes in the current information distribution structure[14]. The availability of cameras that are now integrated in wireless communication devices, makes shooting easier and faster. The media industry must also maintain their existence as providers of factual information following the development of communication technology and people's lifestyles, and open opportunities for active community participation to participate in selecting and disseminating information.

\section{Conclusion}

This study concluded that the program "My Trip My Adventure" (MTMA) can build a natural and cultural tourism entities in Indonesia. This can be seen through the television journalistic approach, where the exploration of Indonesian natural tourism is visualized by taking camera angles which are dominated by the Extreme Long Shot, Long Shot, and Medium Long Shot techniques, with the dominance of the middle frame. It aims to create visual strength from the element of beauty and sharpening the visual elements of a panoramic object. This can build pleasure in the eyes of the audience as a visual consumer, so that it is expected to satisfy and fulfill the desire for adventure. In addition, MTMA is also an effective promotional media, because it synergizes with the Kemenpar program to present "Wonderful Indonesia" through areas from Sabang to Merauke. The MTMA program host is able to represent today's young generation who are energetic, dynamic, intimate, fashionable and interactive with the audience. MTMA shows can also encourage ecotourism programs and are easily accessed through youtube media, so that it can encourage the dissemination of information about potential tourist areas. Indirectly, MTMA not only presents adventure in nature, but also brings a message about values in a socio-cultural environment. Entities built through MTMA have distinctive features that are easily recognized and remembered by the public through the visual language of images that are displayed as visual spaces, namely an adventure space about Indonesian natural and cultural tourism in an informative and entertaining way.

\section{References}

[1] Wijanarko, "Pertumbuhan Pariwisata Indonesia Peringkat 9 di Dunia," Tempo, 2018. [Online]. Available: https://travel.tempo.co/read/1139099/pertumbuhan-pariwisata- 
indonesia-peringkat-9-di-dunia.

[2] A. Mustafa, "Video Promosi Wisata Indonesia Menang Penghargaan Dunia," CNN Indonesia, 2017. [Online]. Available: https://www.cnnindonesia.com/gayahidup/20170915191913-269-242067/video-promosi-wisata-indonesia-menangpenghargaan-dunia.

[3] M. Danesi, Pesan, Tanda, dan Makna. Yogyakarta: Jalasutra, 2011.

[4] Detik Travel, "Komunitas My Trip My Adventure Promosikan Pariwisata Indonesia," Detik, 2017. [Online]. Available: https://travel.detik.com/advertorial-news-blocktravel/d-3623465/komunitas-my-trip-my-adventure-promosikan-pariwisata-indonesia.

[5] B. Block, The visual story: creating the visual structure of film, TV and digital media. Waltham, Massachusetts: Focal Press, 2013.

[6] G. Burton, Membincangkan televisi: sebuah pengantar kajian televisi. Yogyakarta: Jalasutra, 2011.

[7] P. Robin, "Analisis Produksi Program Fashion 'Ilook' Di Net TV,” 2014.

[8] J. A. Walker and S. Chaplin, Visual culture: An introduction. Manchester: Manchester University Press, 1997.

[9] A. Fachruddin, Dasar-Dasar Produksi Televisi: Produksi Berita, Feature, Laporan Investigasi, Dokumenter Dan Teknik Editing. Jakarta: Kencana Prenada Group, 2017.

[10] L. Natadjaja, D. Setyawan, and H. Limantara, "Analisis Sudut Pandang Kamera (Studi kasus: Film Jelangkung dan Film The Ring 1),"Nirmana, vol. 7, no. 2, pp. 152-160, 2005.

[11] W. Gunarti, Y. A. Piliang, and A. Syarief, "Wacana Visual Talk Show "Mata Najwa': Melihat Bahasa Tubuh Partisipan sebagai Kekuatan Visual,” Panggung, vol. 23, no. 4, pp. 369-385, 2013.

[12] E. Mingkid, "Penggunaan Media Komunikasi Promosi Pariwisata Oleh Pemerintah Kota Manado," Sosiohumaniora, vol. 18, no. 3, pp. 188-192, 2015.

[13] M. Fauzi, "Penguatan Informasi Ekowisata Melalui Film Dokumenter Di Keluratahan Sei Mempura," J. Pustaka Budaya, vol. 3, no. 1, pp. 46-56, 2016.

[14] W. Respati, "Transformasi Media Massa Menuju Era Masyarakat Informasi di Indonesia," Humaniora, vol. VOL.5, no. 9, pp. 39-51, 2014. 